\title{
Applying the Preventive Conservation for Securing Mural Paintings in El Sakakeny Palace
}

\author{
Kholod K Salama ${ }^{1 *}$, Mona F Ali² and Abubakr M Moussa² \\ ${ }^{1}$ National Museum of Egyptian Civilization, Egypt \\ ${ }^{2}$ Faculty of Archaeology, Conservation Department, Cairo University, Egypt
}

Submission: July 28, 2018; Published: August 26, 2019

*Corresponding author: Kholod K Salama, National Museum of Egyptian Civilization, Cairo, Egypt

\begin{abstract}
The preventive conservation is more important than restoration process. As it concerns about controlling the deterioration factors and preventing it's occurred in the surrounded area. The historic palaces suffer from the deterioration factors which facing the building walls with all kind of arts applied on it such as mural paintings. The wall inside any ancient building exposed into different deterioration factors which surly transfer into the mural paintings applied on that interior walls. So controlling humidity, temperature and light which affect the mural paintings can be stopped and prevent before accelerating currently the preventive conservations is presented as a case study of the sakakeny palace which contains many kinds of Magnificent paintings to control the surrounded area of the paintings without any direct treatment for paintings.

Keywords: Preventive conservation; Mural paintings; Relative humidity; Temperature; Fire
\end{abstract}

\section{Introduction}

All paintings existed inside sakakeny palace considered a unique art form, need accurate and special treatment so the preventive conservation involves any actions taken to prevent or delay the deterioration of mural paintings. The primary goal is to identify and reduce potential hazards to mural paintings with thoughtful control of their surroundings using different instruments.
El Sakakeny Palace has a great number of mural paintings, contains all techniques of mural paintings which painted with Italian artists such as:

a. The mural paintings which applied on the wall directly almost all walls of halls covered with mural paintings (Figure $1 \mathrm{~A})$.
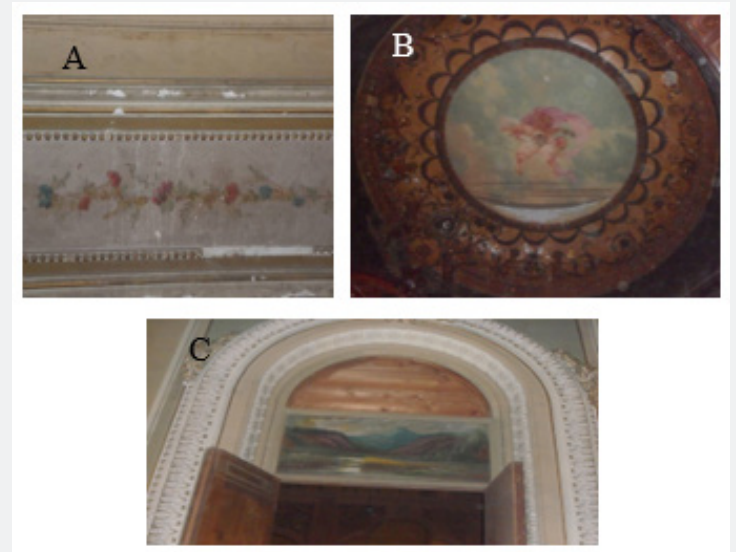

Figure 1: The three techniques of mural paintings in El Sakakeny palace.

A. The mural paintings applied directly on the walls.

B. The mural paintings applied on canvas.

C. The mural paintings applied on panels. 
b. The mural paintings applied on canvas especially on ceiling (Figure 1B).

c. The mural paintings which applied on panel or on the wooden ceiling as El Sakakeny palace which contain beautiful draws on the wooden doors inside the palace (Figure 1C).

All those techniques suffer from deterioration factors such as relative humidity, air pollution and difference in temperature (Figure 2). So, the mural paintings even the recently restored can be suffered again because of the Absence of monitoring temperature and humidity devices. Those mural paintings need applying The Periodical Conservation steps which mean the Preservations of mural paintings as known" protect is better than cure " so all restorers must watch the mural paintings carefully and accurately to control temperature, relative humidity using hygrometers, Protecting those mural paintings from the air pollution using filters and protecting them from fire using fire alarms. As the palace was recently exposed to vital fire in basement caused serious deteriorations as the wooden ceiling has been crashed and soot deposited on the walls (Figure 2).
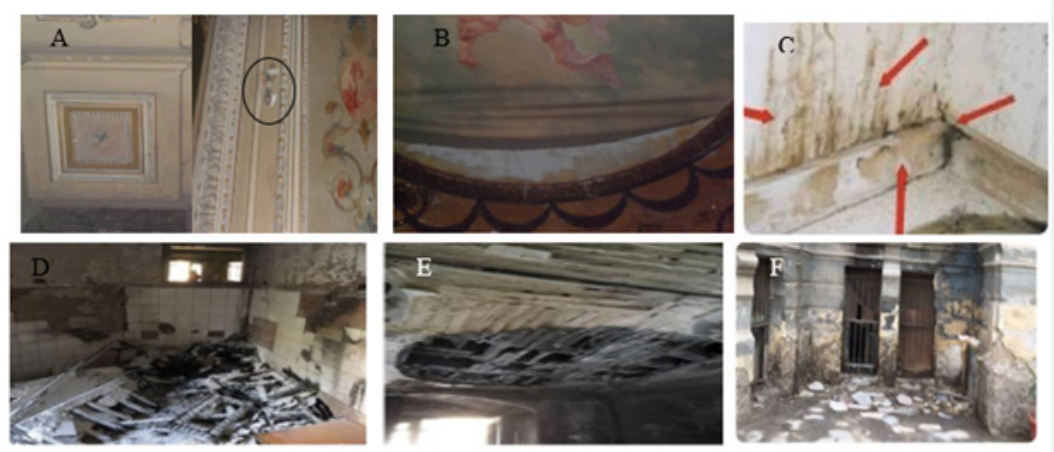

Figure 2:

A. Deposition of pollutants on the surface of the paintings and using the random tungsten lamp causing detachment of the paint layer.

B. The difference in humidity and temperature caused the separation of canvas out of the wall.

C. Absence of monitoring temperature and humidity devices encourages the appearance of cockroaches with their protein content.

D. Fire caused serious deteriorations.

E. Fire caused serious deteriorations.

F. Soot deposited on the out wall of the palace.

That fire caused accelerating of temperature and decrease of humidity content so the gypsum converted to Anhydrite as the following formula:

Gypsum $\rightarrow$ Anhydrite

$\mathrm{CaSO}_{2} \mathrm{H}_{2} \mathrm{O} \rightarrow \mathrm{CasO} 4$

led to the cracks and split of the painting layers.

\section{Materials and Methods}

Hygrometer is an instrument measures humidity using the condensation temperature in the surrounded area the way of use:

a. Fill the water bottle and screw it on to the instrument.

b. Hang the hygrometer (by the loop at the top) on a wall or a tree, for instance, for at least five to 10 minutes before taking the measurements. The instrument should not be in direct sunlight.

Air conditioner which has filters used to control the temperature in the surrounded area and to purify the polluted air the way of work:

i. Air conditioners use chemicals that easily convert from a gas to a liquid and back again. This chemical is used to transfer heat from the air inside of the hale to the outside air. ii. LED lamps (light emitting diode) which haven't any thermal effect, the way of work:

iii. A two-lead semiconductor light source. It is a pen junction diode that emits light when activated. When a suitable voltage is applied to the leads, electrons are able to recombine with electron holes within the device, releasing energy in the form of photons.

iv. Fire Alarms are instruments used for detecting the fire in historic palaces and the fire extinguishers to resist the fire, The way of work:

v. Extinguishers work by removing heat from the fire. Dry chemical extinguishers are tanks of foam or dry

vi. powder with compressed nitrogen as the propellant. They work by smothering the fire: when you put a layer of powder or foam on the fire, you cut the fuel off from the oxygen around it, and the fire goes out.

\section{Results and Discussion}

\section{The Hygrometer device}

Due to the link between temperature and relative humidity as any change in temperature followed by a change in humidity so these factors can't be separated so the relative humidity 
must be not exceeding 65\% - 45\% [1]. As the high humidity helps growth and reproduction of microorganism [2] and low humidity lead to fragility of the archaeological material [3] And the frequency in relative humidity working on separation of color layers and negatively affecting plaster layers. Recording the relative humidity is consider a basic step in the process of conservation and there are many devices for measuring it [4] like Hygrometer and Data logger [5] Figure 3.

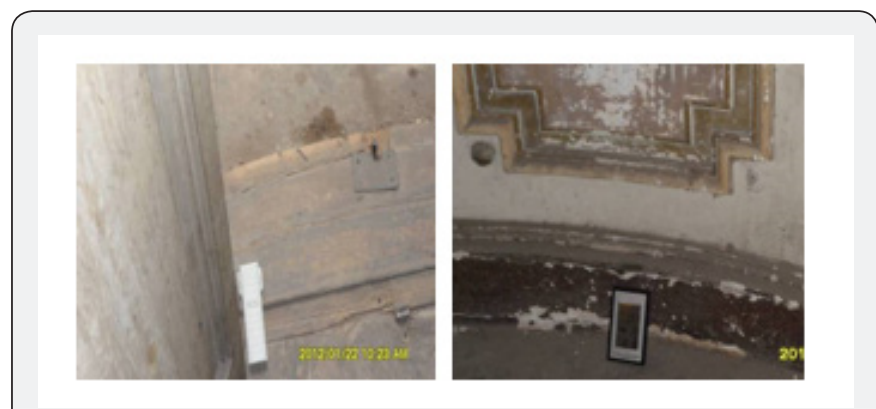

Figure 3: The Hygrometer which used for measuring humidity and temperature in and out of El Sakakeny palaces.
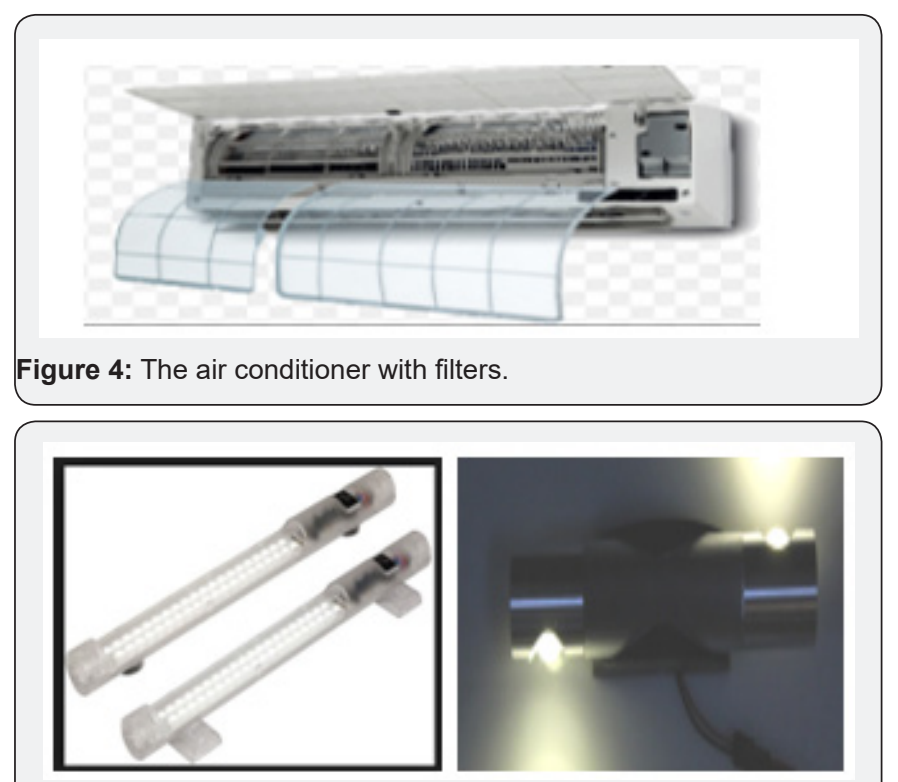

Figure 5: The air conditioner with filters.

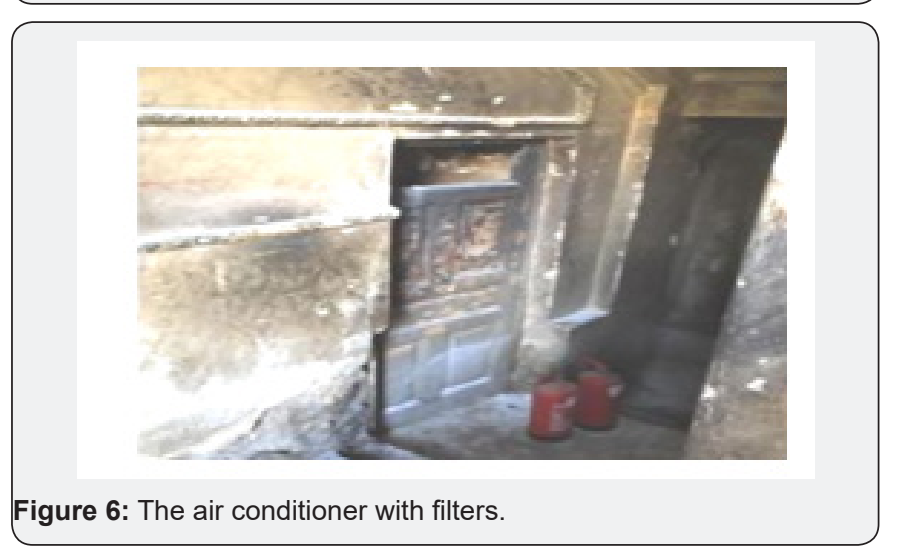

\section{The Air Conditioner}

The air conditioner with filters Figure 4 is the best way to control the relative humidity and temperature. the device may close automatically in case of reaching temperature, and relative humidity limits [6] and the filters prevent dust and gas pollution [7]. The use of filters to purify the air of solid waste and some gases such as gas sulfur dioxide, ozone, oxides of nitrogen. This filter can purify the air from the dust efficiently 99\% [8] (Figures 5\&6).

\section{The LED Lamps}

To control the light system in El Sakakeny palace must use the following steps:

a. The LED lamps Fig.5 haven't any thermal effect so using them are very safety for the mural paintings in El Sakakeny palace as the light intensity must be less than 150 lux for colored mural paintings [9].

b. Reduce the time of exposure to light using the system of automatically light ( self-lighting ) since there are visitors watching the mural painting and this system is very accurate and this system can cause preservation to mural paintings as for example if the hall number 1 in palace $A$ is empty so no need to be lighted so this system will associate the visitors with the light [10].

\section{The fire Alarms and Fire Extinguisher}

A fire alarm system has a number of devices working together to detect and warn people through visual and audio appliances when smoke, fire, carbon monoxide or other emergencies are present. These alarms may be activated automatically from smoke detectors [11] El Sakakeny palace has been exposed to fire because of absence of stem alarm detector and the Fire extinguisher were kept away of workers in the palace Fig.6 so any person need to know how to use it by Pulling the pin on the extinguisher. Aim the hose nozzle low toward the base of the fire. Squeeze the handle to release the extinguishing agent. Sweep the nozzle from side to side at the base of the flames until extinguished. So, learning the ways of using extinguishers is an important step in applying the preventive conservation.

\section{Conclusion}

This paper is presenting the periodical conservation steps in El Sakakeny palace which contains different techniques of mural paintings suffering from many deterioration factors and on the top the fire accident which recently happened in the palace.

i. 1-control relative humidity and temperature according to the hygrometer results and using a suitable air conditioner to reach the suitable temperature and humidity in order to prevent the growth of microorganisms and prevent the differential rates of expansion and contraction in the mural paintings layers. 
ii. 2-filters in air conditioner purify the air from dust and gases.

iii. 3-control the light using safety kinds of lamps like LED lamps which haven't any thermal effect.

iv. 4-and finally protecting the palace from fire using advanced alarms to detect any possible fire and the fire extinguisher to resist fire if happened as the loss of the value historic palaces can't be compensated with no money.

v. 5- Courses for the workers to learn how to deal with the fire alarms and fire extinguishers must be an important step in preventive conservation.

\section{References}

1. Maekawa S, To Ledo F (2000) Aclimate Control System for Holly Bourne Cottage, Jejyll Island, Historic District, Georgia, p. 21

2. Guths S (2002) Humidity Control in Small Spaces and in Displays, Scientific Methodology in the Conservation \& Restoration of Culture Goods, 11th Congress of the ABRACOR Barazilian Association of Conservators - Restorera of Cultural Goods p.65.
3. Thomson G (1989) The Museum EnvironmentDButter Worthheinemann. (2nd edn), p. 15.

4. Lofonoine R (1975) Recommended Environmental for Museum Archives \& Art Galleries, In Canadian Conservation Institute, p.3

5. Nazar Off WW, Ligocki MP, Lynng Salmon, Theresafall GR (1992) Air Borne Particles in Museum S, The Getty Conservation Institute p. 31.

6. Dean D (192) Museum Exhibition. Rout Ledge, London, UK, 2: 11.

7. Glinchy MC (1994) Conservation; The Metropolitan Museum: Ne, C "Color and Light in the Museum Environment" In the Changing Image: Studies in Paintings W York.

8. Middletion A, Uprichard A (2008) The Nebamun Wall Paintings. The British Museum p. 30.

9. Demas M (2003) Conservation and Management of Archaeological Sites, The Gci Project Bibliographie Series, The Getty Conservation Institute p. 3.

10. Edaward TJ (1990) Cotrolling Museum Fungal Problem?Candian Conservation Institute Technical Bulletin p. 5.

11. Keene S (2002) Managing Conservation Museums, Second Edition, Butter Worth, Heinemann, Oxford, UK, p. 21.

\section{Your next submission with Juniper Publishers} will reach you the below assets

- Quality Editorial service

- Swift Peer Review

- Reprints availability

- E-prints Service

- Manuscript Podcast for convenient understanding

- Global attainment for your research

- Manuscript accessibility in different formats

( Pdf, E-pub, Full Text, Audio)

- Unceasing customer service

Track the below URL for one-step submission https://juniperpublishers.com/online-submission.php 